\title{
The market and water management reform in Peru
}

\author{
Eduardo Zegarra
}

$\mathrm{T}$

his article examines the unsuccessful attempts made in the 1990s to introduce a market for water in Peru. This reform was thwarted because market operations were identified with water rights privatization, even though a market can perfectly well operate on a basis other than that of private rights, with the State retaining full ownership of the resource. The argument made here is that if these shortcomings were corrected, the creation of a water market would be desirable to improve allocation and management of water and to deal with the increasingly serious difficulties associated with the administration of water access, the lack of investment incentives and serious problems of efficiency and equity. The economic advantages and disadvantages of a water market are analysed, as are the legal and regulatory prerequisites for promoting the kind of market that would really improve water allocation in the increasingly necessary institutional reform of this sector in Peru.

Eduardo Zegarra

Senior Researcher at the Group for Analysis of Development (GRADE),

Lima, Peru 


\section{I}

\section{Introduction}

Over the past few decades, creating market mechanisms for water allocation has been one of the most controversial ideas in the debate about how best to manage natural resources. This idea, which originally came up in certain developed countries, has begun to be raised in some developing ones that face growing water shortages, such as Peru.

During the 1990s the Peruvian economic system underwent a profound change, shifting from an approach that relied heavily on State intervention in the economy to a model of far-reaching liberalization and noninterference by the State in the market. As part of this economic liberalization approach, a radical proposal was made to reform water legislation by privatizing water rights and introducing a market system of allocation, a model taken from the Chilean legislation then in force. This option was not ultimately adopted, owing to the objections of different social and political actors, and it was never the subject of much public debate.

Against this background, a new government initiative was recently launched to reform the legislation and create new water management institutions. This initiative drew on many of the ideas and debates of the 1990s, but it definitely ruled out the idea of privatizing water, while keeping open the option of introducing market mechanisms for its allocation.

This proposal is being widely debated in Peru. One of the issues that is still controversial is the idea of introducing a water market, as this continues to be viewed as problematic by many social and economic actors, particularly farmers, who consume $85 \%$ of the water used in the country. The fear is that a market mechanism may reduce access to water for agriculture and favour other sectors with greater economic power, and that it may become a source of legal uncertainty for acquired rights. Likewise, different groups believe that the water market may result in access being affected by monopolistic dominance, and thus in water access becoming more unequal. Generally speaking, opposition to the idea of a water market has arisen as part of an adverse reaction to water privatization, confusing two different concepts.

It now seems essential for the future of water management reform in Peru that the advantages and disadvantages of a water market for the different user types and for integrated water management be set forth in a coherent way. It is also important to examine and discuss the legal and regulatory requirements for an efficient and sustainable market in a resource with the special characteristics of water. The aim of the present article is to review these issues and analyse in depth the advisability and practicalities of introducing market mechanisms for water management in Peru, a country that has a history of controversy in this area dating back to the 1990s.

\section{II \\ The attempts to reform Peruvian water legislation in the 1990s}

A look at the legislative agenda of the Peruvian Congress in the 1990s will show that almost every year there were motions to debate and pass a new water law, some of them tabled by the executive and others by members of Congress itself. None of them was successful, however, which is why the country still does not have modern legislation on this very important subject. In this section, the most important initiatives will be described and the factors that have hitherto made legislative change impossible will be examined.

Our analysis of these factors centres upon water privatization and the operation of a market in this resource. Both issues, which have frequently been confused and poorly explained, have clearly contributed to the difficulty of bringing about the needed legislative change with the consent of users. 


\section{Background}

Water legislation in Peru has undergone partial reforms in the last 30 years as administrative requirements and particular needs or emergencies have dictated. Water management between 1970 and 1980 tended to continually weaken the system of authority and planning established by the 1969 water act (Ley General de Aguas). In the late 1980s the Government decided to transfer critical water administration and distribution functions to user organizations (mainly irrigators), including the collection of tariffs. Then the severe hyperinflation of the late 1980s greatly weakened the State and its ability to finance public activities, including water management.

In 1990 a major political and economic shift began, marked by economic liberalization and a subsequent weakening of the democratic system. ${ }^{1}$ In particular, in 1991 the Government began to adopt a series of drastic measures involving economic liberalization and privatization of State assets, with the basic objective of promoting private-sector investment. There were specific investment promotion measures for the different sectors. For one of these, agriculture, a legal instrument was passed - the Ley de Promoción de las Inversiones en el Sector Público Agrario (D.L. 653) - that created certain incentives for private investment in the extraction of underground water, in contravention of the general law of 1969. At this stage the Government began to consider the need to enact a new water law compatible with the economic liberalization then in progress.

\section{The first attempt: copying the Chilean model}

Thus, in late 1991 the Ministry of Agriculture decided to engage a Chilean consultant to draft a water bill very similar to that of Chile, which in 1981 had passed a Water Code that privatized water rights and fully introduced a market mechanism.

This initial proposal, however, was supplemented by the Ministry of Agriculture with a series of provisions to preserve bureaucratic powers in this area. Thus, the draft that finally emerged was a mixture of liberalization of rights and bureaucratization of administration.

\footnotetext{
1 The regime of President Alberto Fujimori dissolved Congress in 1992, and then convened a new Congress with constitutive powers which was to pass a new constitution in 1993. Fujimori's Government became increasingly authoritarian during the 1990s.
}

The original proposal also had problems of a formal character, however. For example, it was incompatible with the Constitution in force (of 1979), which declared natural resources to be the property of the nation; thus, water could not be privatized.

Furthermore, some doubts began to arise about the Chilean legislation at that time: it was claimed, for instance, that it encouraged speculation in water rights by certain economic agents with a detrimental impact on water access for vulnerable (indigenous) social groups, and that its institutional framework was ill suited to dealing with intersectoral conflicts, among other things. These criticisms were actually evaluated by the democratic Government that came to power in Chile in 1990, when it carried out a review of existing legislation.

Besides all this, the original proposal was not properly analysed or discussed with a variety of important governmental actors or among users. These latter, and farmers in particular, rejected the proposal outright. The main misgivings expressed by them concerned the operation of a water market, which they saw as having the potential to deprive them of access to this resource through the operation of economic interests. Environmentalist groups and water managers were also opposed to the law, however, as they were concerned about provisions in it which would weaken State powers to regulate water.

\section{The second attempt: some changes to the model}

Between 1993 and 1994 another attempt was made to pass a new water bill, efforts being made this time to overcome some of the limitations of the previous one. In 1993 a new Constitution was passed. While continuing to treat natural resources as the property of the nation, it stipulated that they could be granted on a concessionary basis. It also stipulated that Congress should pass a constitutional law on natural resources before passing laws dealing with specific resources such as water.

In these new circumstances, the Ministry of Agriculture, under pressure from the Ministry of Economic Affairs and Finance, decided to relaunch its legislative proposal, but this time with some amendments. For example, it now included a tax on water rights with a view to preventing speculation. It also incorporated some ideas about the management of water at the basin level and consideration was given to some limitations on the ownership of water from natural sources. 
This new bill had a very good chance of being passed, especially in 1995-1996. At this stage, however, opponents of the Ministry of Agriculture proposal emerged within the Government itself, particularly in relation to drinking water and sanitation, as they were concerned by the possibility that the law might overturn the priorities already set for drinking water consumption. The bill was not ultimately passed and when the Ministry of Agriculture changed, a new situation arose.

\section{The third attempt: a broader, multisectoral approach}

Following on from these efforts, in the 1996-1998 period a third attempt was made to enact a new water bill in Peru. A multisectoral commission would be set up within government, involving the main sectors concerned: agriculture, water and sanitation, energy and mining, economy and finance, and others. At this stage a more comprehensive proposal for legislative reform was to be drawn up, ruling out the privatization of water rights and adopting a multisectoral approach to this resource whereby a multisectoral authority would be created instead of the traditional authority within the agriculture sector.

This third attempt was never to come to fruition, as the agriculture and economy and finance sectors lost interest in the subject. In 1997 the Constitutional Law for the Sustainable Use of Natural Resources was finally passed, creating the general framework within which specific laws like a water act could be created.

In 1999 and 2000 the political situation in Peru became very fraught: President Fujimori was seeking re-election for the second time and the country had become seriously polarized. In those years there were no major water legislation initiatives.

\section{The most recent initiatives}

In late 2000 the Fujimori Government fell and a transitional Government headed by Valentín Paniagua took office, before calling a general election and handing over power in mid-2001 to the current president, Alejandro Toledo. During the transitional Government there was an attempt by the agriculture sector to generate new legislation, with a water bill that was published well in advance and debated by the public for several months. This proposal contained some interesting advances, but it was not an improvement on the multisectoral effort of 1997-1998 as it still had a clear sectoral bias towards agriculture and its definition of water rights contained ambiguities that did not clarify the complex legal status of this resource.

Subsequently, under President Toledo's Government, Supreme Resolution 122-2002-PCM was enacted, creating the Multisectoral Commission to draft a new water bill. The Commission, which would include members of all the ministries and public bodies concerned with water as well as private users in the agriculture, mining, industry and urban sectors, was set up in January 2003. It worked for four months and produced a draft water bill which was publicized in May that year so that it could be debated by the public.

The bill drafted by the Commission accepted the principle that water was indivisible and that its exploitation by multiple users required a balanced institutional structure with a single technical and regulatory authority to enforce the law and safeguard the resource in its natural sources. ${ }^{2}$ The draft also provided for an innovative way of binding the institutional arrangements for water into the ongoing regionalization process. Consejos de Cuenca (River Basin Councils) would have been created at regional and multi-regional level (depending on the actual characteristics of river basins) as the basic authorities for water management in the decentralized administrations. In relation to these aspects there were some initial disagreements between the members of the Commission, but a reasonable consensus was ultimately reached.

The part of the legislative proposal that generated adverse reactions, however, especially in the farming sector, was the proposed new system of water rights based on the idea of water "concessions", as set out in the Constitutional Law for the Sustainable Use of Natural Resources and the current Constitution itself. Water concessions would give their holders a right of usufruct over the resource under set conditions, but would not give them ownership.

\footnotetext{
2 The bill proposed to create a single national water authority of high administrative rank, the Instituto Nacional del Agua (National Water Institute), responsible for enforcing regulations, monitoring water quality and quantity and granting water rights, among other important functions. The Instituto Nacional del Agua would have come under the Presidency of the Council of Ministers, owing to its multisectoral character, but would have followed the policies and guidelines laid down by a Consejo Nacional de las Aguas (National Water Council), also a multisectoral institution with both public- and private-sector representation.
} 
Again, in accordance with what is laid down in the Constitutional Law, the proposal included provisions that allowed water concessions to be traded by their holders, always provided the original conditions under which they had been granted were met (i.e., provided that no important features of the actual concession were altered). In practice, this was tantamount to allowing a market in water rights, albeit under different conditions from those laid down by the Chilean legislation, which is more privatist. In other words, a market could be operated, but under the conditions laid down when the concessions concerned were granted and without prejudice to public ownership of the resource.

\section{The initial reactions}

The first reaction of users in the farming sector - the most important one socially and the largest user of water - was hostile to the draft, as this was regarded as "a new attempt to privatize water". This reaction, which cannot be seen as justified by the form and content of the proposal, even led to a national strike in the sector and thence, in June 2003, to the establishment of a state of emergency in the country, in the midst of other mobilizations by teachers and truck drivers.

In this situation, the Government decided to give water users in the farming sector six months to come up with an alternative proposal. The proposal drafted by agricultural users was recently submitted to Congress, and it is clearly hostile to the idea of a water market. It also insists on a sectoral approach to water, with agriculture pre-eminent above other sectors.

However, this hostility to the idea of a water market basically centres around water privatization. This is despite the fact that the two concepts are distinct, since it is possible for a water market to operate without water access rights having the attributes of private property. ${ }^{3}$

The experience described shows that there has not yet been a thorough debate in Peru as to the advantages and disadvantages of bringing in a market mechanism for water allocation or as to the right way of doing this so that management efficiency, equity and sustainability are improved. In the absence of such a debate, the hostility to reform proposals does not seem to be well founded, and action is needed urgently to remedy the situation.

\section{III}

\section{A market for water: advantages and disadvantages}

This section will analyse the advantages and disadvantages for society of bringing in market mechanisms for water allocation, both in conceptual terms and for the specific case of a country going through a management crisis, like Peru. The evaluation will be carried out in the light of economic, social and environmental objectives, and from the point of view of integrated water management.

\section{Water markets and economic efficiency}

Properly functioning markets are one of the most effective means of achieving economic growth, understood as a continuous, sustainable expansion in the material output of the population as a whole. For a specific good, a properly functioning market enables factors to be mobilized as required so that society as a whole obtains from them the greatest net benefit possible.

In the case of water, which is a production input for many activities, proper functioning of the market concerns the allocation of this scarce resource to different economic activities (i.e., activities that generate economic value or benefits) or to different economic agents with differing preferences. In a situation where a (scarce) input has to be allocated to various alternative activities or to a variety of agents, the market can be said to be working well as an allocation method when the input concerned goes to

\footnotetext{
${ }^{3}$ In other words, privatization of water rights is not a necessary condition for a market in water allocation, since trading can be in conditional rights. This is what happens in most developed countries with water markets.
} 
the activities or agents that set the highest value on it.

In other words, the input will have an "opportunity cost" for each of the possible activities or agents, and the most efficient allocation will be that whereby no activity or agent has a different opportunity cost for the input. If this were to happen, the input could be reallocated, and society would obtain a greater net benefit.

It is important, then, to realize that the efficiency gains from the operation of a water market can be substantial, to the extent that water is allocated to the highest-value activities. Another crucial advantage of the operation of a water market is that it tends to encourage private investment both in infrastructure and in water-saving techniques, insofar as private-sector agents are able to appropriate the efficiency gains these investments bring at the prevailing opportunity cost.

Efficiency gains can be affected, however, by some fundamental factors which influence the operation of markets. These can be classified into three types: transaction costs, externalities and limited competition. These factors can reduce and even reverse potential efficiency gains from the operation of a water market. We shall now consider how this may happen.

The issue of transaction costs relates to the resources needed for the market to operate, both legally and in terms of the information required for transactions. When two agents are to trade a good, information on important attributes of that good may be limited and/or asymmetrical, and this affects the potential benefits of the exchange. Likewise, the legal requirements for carrying out transactions may be burdensome and act as another complicating factor. Thus, in a market with high transaction costs, potential efficiency gains are reduced and in some cases even disappear, if the water market cannot operate.

This market is a typical example of high transaction costs for a variety of reasons (Young, 1986; Colby, 1990). Firstly, water is a mobile good that is difficult and costly to measure, so that resources are needed to gauge its quantity and quality accurately. Secondly, the legal status of water is usually complex and an efficient technical and administrative apparatus is needed to establish clear ownership rights and maintain and update them over time. Lastly, the reallocation of water in a fixed distribution system may require costly infrastructure and operational alterations, items that feature as transaction costs in any market operation.

But while transaction costs tend to limit the efficiency gains of a market (or even prevent it operating), ${ }^{4}$ the presence of externalities can actually result in net losses of efficiency in some situations. There is an externality when the individual costs of an economic action are smaller than (or different to) its social costs. ${ }^{5}$

In the case of a water market, one of the possible consequences of externalities is that users may become more uncertain about their rights over this resource when a market starts to operate. If there is not a suitable institutional and regulatory ${ }^{6}$ framework to prevent the market mechanism from affecting the rights of third parties, efficiency losses may arise as users' access becomes less secure. This is a real possibility in traditional irrigation systems in developing countries, as these lack the technical and institutional capabilities needed to ensure that the complex externalities of potential transactions are fully internalized by the parties to the transaction.

Lastly, one characteristic of an efficient market is that it offers no opportunity for certain agents to manipulate it for their own benefit. In other words, there need to be conditions of open competition or market entry. Only in conditions of open competition are market actors not in a position to manipulate prices and thus enhance their profits to the detriment of society at large. This is a major problem when the technological conditions exist for economies of scale in the provision of a good or service, since under these circumstances natural monopolies arise. The main issue in this case is the regulation of monopolies to attain the greatest social benefit possible under existing technological conditions.

To sum up, the water market may generate efficiency gains, but these will only materialize if the market operates with low transaction costs within an institutional framework that deals appropriately with externalities, and is open to new entrants and competition.

\footnotetext{
${ }^{4}$ Transaction costs can certainly reduce efficiency gains, but in situations where water is increasingly scarce these costs tend to be lower as a proportion of the benefits expected, and thus to be less of a constraint on the operation of the market.

${ }^{5}$ In the operation of a market, externalities may arise when there are non-participating agents who may be positively or negatively affected by a transaction. In other words, the opportunity cost perceived by the agents involved in the transaction does not fully incorporate the costs perceived by all those concerned by it, so that the outcome of the transaction may reduce the benefit to society instead of adding to it.

${ }^{6}$ See section IV below.
} 


\section{Water markets and equity}

When we speak of achieving equity we have in mind the goal of attaining equality opportunities so that citizens can fully develop their physical and intellectual potential in a context of democratic institutions and individual freedoms. A properly functioning market can promote equity in many circumstances. For example, if there is a technological innovation that favours greater use of unskilled labour (one of the most important assets of the poor), ${ }^{7}$ a properly functioning labour market will substantially raise the returns on unskilled labour and thus make a significant contribution to a more equitable society.

In the case of water, criticisms of the market mechanism frequently allude to the possibility that the exploitation of this resource will become less equitable. Some economists respond by saying that it is almost impossible for a water market to undermine equity, since no agent would willingly participate in a water transaction that ultimately detracted from his or her well-being (Donoso, 1994; Lee and Juraslev, 1998). However, adverse consequences for equity may derive from possible side-effects of market operations that do not necessarily affect those involved in the transaction.

The existence of high transaction costs may mean that only some agents, generally those with most economic power, participate in the market. In certain contexts this can affect equity. The most important problem of equity entailed by the operation of a water market, however, comes from the presence of externalities affecting vulnerable groups with few means of responding to changes in the ground rules and in water allocations. Thus, a water transaction may improve the well-being of the parties to the transaction, but have an adverse effect on the well-being of other agents who are not participants, without this latter effect being fully incorporated into the operation. This can happen precisely because in a market context resources are also needed to oppose transactions that affect third parties. It is possible that those affected may be the poorest actors, who are the least well endowed with the resources needed to oppose transactions. ${ }^{8}$

\footnotetext{
${ }^{7}$ We cannot regard as equitable a situation where large sections of the population lack the minimum material conditions for existence (poverty and extreme poverty), since these people cannot fully develop their potential even if they are living in a democracy and enjoy individual freedoms.

${ }^{8}$ One problem of equity often associated with the introduction of water markets derives from the original allocation of water rights. In many particular situations, rights initially go to the agents who
}

\section{Water markets and environmental objectives}

By environmental objectives we mean those concerned with the attainment of conditions for the sustainable exploitation of natural resources and for the proper conservation of environmental assets valued by present and future generations.

The relationship between environmental objectives and the functioning of the water market can be very complex. In an institutional context where environmental objectives are given no real expression either within institutions or among decision makers, the water market will tend to reflect this situation and is very unlikely to have positive environmental effects (Brisbane Institute, 2002). For example, if the overall effect of economic policies is to favour rapid economic growth with intensive use of contaminating processes, the existence of a water market will only amplify this, since water will be allocated to the activities favoured by these policies.

This general consideration notwithstanding, market mechanisms can be useful for attaining environmental objectives under various circumstances. For example, activating a water market is a very good way of dealing with growing demand for this resource. The traditional government response to growing demand has been to construct water control and distribution infrastructure. These projects have usually had a negative environmental impact, so the market solution is one option for avoiding or reducing effects of this kind.

A water market can also play an environmentally useful role, provided the necessary environmental institutions exist, in protecting certain habitats that are very important to different social groups. In developed countries it has happened that under certain circumstances these groups or the State have acquired water rights to ensure the conservation of particular ecosystems, without having to go through complex and very expensive administrative reallocation schemes. To do this, however, it is necessary for these groups actually to have purchasing power or for the State to have the fiscal resources for this type of operation. In developing countries there is very little scope for this.

\footnotetext{
are best placed, economically and politically, to claim them. There is no reason why this process should be equitable, and it may result in major social groups losing water access rights because they lack political or economic power. This possibility is not directly linked to the operation of the water market, but to the allocation of water rights. A reallocation of rights that did not entail market operations would come up against the same problem.
} 


\section{Multisectoral water management and the market mechanism}

As was pointed out earlier, water is a mobile, multipurpose resource that is used for virtually every important economic activity: energy, agriculture, industry, mining, fish farming, urban consumption and sanitation, recreation and so on. The greatest economic benefit that the existence of a market opens up is the opportunity to allocate this increasingly scarce resource to the activities society most values. Likewise, the potential gains from the functioning of a water market can also arise within specific sectors, where there might be great inefficiency in the allocation of water and large differences in the value society sets upon activities. ${ }^{9}$

Because of its special characteristics, water inevitably requires a management system that allows it to be used in an orderly and peaceful fashion in the face of multiple demands. In any water control and distribution system, technical decisions have to be taken at certain levels of the system in relation to the amount and quality of the resource; operation and maintenance; distribution of the water in accordance with established criteria; conflict resolution; penalization of actions by users that affect the normal allocation process, and other matters.

This range of functions cannot be dealt with spontaneously by individual users of a system. In some form or other there needs to be an "authority" to perform these functions and take the necessary decisions. Taken together, these short- and long-term decisions constitute what we know as water management, and this requires specific resources and technical, organizational and coordination capacities. The ways in which these functions are discharged in different settings may vary for legal and historical reasons, but the general effect will be to make orderly water use viable. It is now time to consider the advantages and disadvantages that might arise from the

\footnotetext{
${ }^{9}$ In each of these activities, market mechanisms for water will be introduced under specific conditions. For example, in sectors where a natural monopoly is the rule (such as energy and drinking water), it is vital for the service provider to be properly regulated to ensure it does not abuse its dominant position. In this case the idea of a market in water rights within an area covered by a single provider does not make much sense; it might only do so were this provider to buy water from other providers or sectors, or sell it to other providers or sectors. The case of agriculture, though, offers a wider range of possibilities for the operation of water markets within the sector: conditions might be suitable for water rights to be traded within irrigated areas and, of course, between agriculture and other activities or other irrigated areas (Zegarra, 2003).
}

introduction of market mechanisms for water management in particular contexts.

One of the clear advantages of operating a water market is that a price is generated for the resource (opportunity cost), something that cannot happen when allocation is administrative in nature. This information is very valuable for efficient water management, and the authority concerned will not have to generate any other information to be able to make decisions whose objective is efficient water allocation. If this is one of the objectives of the authority, having a water market in operation obviously creates a favourable setting within which to achieve it.

Another advantage of having a market operating is the way conflicts over water use between users of a given system can be managed, especially in conditions of extreme scarcity. In systems where allocation is administrative, many users will become extremely dissatisfied with their normal allocations at times of scarcity and will begin to put pressure on the distribution authority. When a market is operating, the different needs and preferences of users in a situation of scarcity can be processed through this market and the authority will not come under pressure that may ultimately weaken it and undermine its legitimacy. Also, if the market works well, the way it allocates water in a situation of extreme scarcity will probably be more efficient and equitable than would be the case with other methods.

The operation of a water market can create a favourable setting for the attainment of efficiency and equity. To achieve these objectives, however, it is also necessary to have some quite specific and complex management capabilities in place.

For the market to operate in an irrigation system, for example, users need to have their individual water rights clearly established and demarcated, and all transactions must be processed and implemented by the water distribution authority. In many cases the authorities are not capable of establishing individual water rights accurately, nor is it easy for them to reallocate individual holdings, owing to the physical constraints of irrigation systems. In these cases a market may not be viable, because the authorities lack the requisite management capabilities.

Likewise, there are conceivable circumstances in which the operation of a water market may give rise to conflicts and increase legal insecurity. If water rights are not clearly established and there are numerous externalities that are difficult to measure and compensate, there is the possibility of serious conflicts 
that could hugely complicate the management of a system instead of facilitating it.

These considerations indicate that the introduction of market mechanisms for water allocation must necessarily be accompanied by new capabilities and, in many cases, by greater regulatory and management powers for the authorities responsible for this resource. It should come as no surprise that water markets in developed countries are usually supervised closely by the authorities concerned. These authorities have the power to block transactions that do not comply with certain technical or legal requirements, and to restrict the activity of the market when the public interest is in jeopardy. Even the distribution authorities chosen by users themselves have restrictive powers vis-à-vis the market, as a way of keeping to a minimum the number of transactions that have adverse effects on third parties. The following section will review some of the legal and regulatory requirements for a properly functioning water market.

\section{IV}

\section{Regulatory requirements for the proper functioning of a water market in Peru}

The first requirement for a water market to operate is obviously a legal one: a new law is needed establishing that water users may trade their water rights (and appropriate the benefits) under certain conditions, in permanent or temporary transactions, within a sector or between sectors. In a legal framework of this type, it is essential to establish an institutional system capable of generating certain elements that are important for the proper working of this market, particularly when it comes to managing and reducing externalities, lowering transaction costs and preventing the emergence of dominant positions in the market.

Firstly, it is necessary to identify the water rights concerned at the aggregate and individual levels, employing some objective parameter such as prior use. This is an extremely complex process in the case of agriculture, where access to water has been heavily distorted by interest groups and there are no proper records of individual or collective use. A complex and tricky task will have to be performed here, that of establishing a basic system of water rights for allocation, taking technical, social and even political factors into account. To this end it is clearly necessary to design a participatory model so that current users can show they have been making peaceful, continuous use of the resource. The establishment of a basic system of water rights is prior to and different from the process of actually awarding these rights.

For water rights to be awarded it is necessary to create and maintain an efficient public cadastre and register of them that gives users full legal security in respect of their rights and enables these to be traded under suitable conditions. Furthermore, the authority responsible for granting water rights has to be able to formalize them reasonably quickly, thus avoiding situations in which rights are unstable once acquired, and to do so at a cost acceptable to users. These tasks, which are very onerous and involve large costs, will have to be performed in their totality by the political and technical authorities, since if this process of recognizing and registering water rights is not carried out then there is no prospect of an efficient water market operating.

In Peruvian agriculture, the great numbers and dispersion of water users suggests that it will not be possible to grant individual titles to farmers in the short term, or even perhaps in the medium term. The most advisable course, then, is to generate formal bulk water rights (en bloque), for example, at the level of irrigation committees (comisiones de regantes), which are smaller units within irrigation councils (juntas de regantes). Individual users may have individualized rights within these bulk rights, but these will be awarded by a process organized and financed by the irrigation organizations themselves.

Also fundamental to the operation of a water market is the regulatory system. As we have noted, externalities are one of the greatest problems with such a market (i.e., the positive or negative external effects that transactions may have on non-participating agents). It is necessary, therefore, to define clearly the powers the water authority has for making transactions 
conditional on a commitment not to generate externalities, or to provide compensation for them, and for giving those potentially affected every opportunity and means to participate in the authorization of transactions. Furthermore, the authorities will have to be highly skilled at measuring the impact of externalities, something that entails better measuring mechanisms and more resources for carrying out studies and engaging specialist staff.

The subject of externalities is especially critical in the case of intersectoral transactions, and in situations where water is reused within the same sphere of use. In both cases it is necessary to have the technical capacity to establish and measure the impact of externalities, so that these can be taken into account when water right transactions are being authorized and negotiated.

Another basic element of regulation are rules to avoid situations of dominance in the water market. An important legal instrument for this purpose is the establishment of a requirement of actual and beneficial use of the water to prevent monopolization of and speculation with water rights and to create incentives for the market to operate more actively. In Peru there is a body responsible for combating monopolistic practices, the National Institute for the Defence of Competition and the Protection of Ownership (INDECOPI); this institution should establish additional parameters to avoid situations of this kind in particular cases.
The regulatory system also needs to give consideration to environmental issues. In Peru there has been a debate on environmental legislation and the instruments the State has at its disposal to attain environmental objectives. Under current legislation, ministries are also the environmental authority, a situation which is unfavourable to the attainment of these objectives. In the case of water, the most important issues are minimum quality standards and the actual ability of the authorities to enforce them. There seems to be a need to strengthen regulatory capabilities in this area by creating a single water authority to safeguard these standards. Another issue is the need to establish the minimum flows required for environmental purposes in rivers, and this could have some effect on the establishment of rights and the operation of the market.

Lastly, the operation of water markets will also have a significant impact on the way water is managed. In the case of agriculture, for example, the idea that access to water depends on a growing and irrigation plan or on what the farmer wishes to sow should be done away with. Moving from this concept to the idea that each user has a water allotment per hectare per year (proportional to the supply available that year, for instance) involves a very large shift in the way water is managed in the main irrigation systems of the Peruvian coast. This will necessitate training for the staff involved in water administration. ${ }^{10}$

V

\section{Experience with water markets}

\section{in other countries}

There is not a large volume of research into the role and implications of water markets, largely because markets of this kind are not easily developed owing to institutional, economic and political factors (Young, 1986). Since the 1980s, however, interest in the subject has increased in both developed and developing countries. In developing countries it has been growing since Chile's water market was opened up in the 1980s, and the subject is now turned to more frequently both by international agencies and researchers and by political authorities and environmental activists, a trend which will probably continue or increase in future given the need to find alternative institutional mechanisms for the efficient allocation and use of this vital resource (Lee and Juraslev, 1998).

At present, most of the theoretical and empirical literature on water markets comes from developed countries, particularly arid zones that are well developed economically such as the west and southwest United States, some regions in Spain, and Australia. Markets play an important role in the

\footnotetext{
${ }^{10}$ Agriculture consumes $85 \%$ of water in Peru.
} 
intersectoral distribution of water in these areas, whereby urban and industrial users acquire water from agriculture. There are also water markets within the agricultural sector in these areas, either for the trading of rights or for temporary leasing of water access. As regards Latin America, some important studies have been carried out in Chile and Mexico, countries where the water market is already a fact of life both in agriculture and in other sectors.

A review of the literature on the subject reveals that many of the authors concerned have begun to analyse in greater detail the advantages and disadvantages of introducing a market mechanism for water allocation at a time when shortages are increasing and the traditional administrative methods of allocation are breaking down. One of the arguments in favour of a market is that users (especially farmers) really are beginning to value water as an economic good whose efficient management can bring practical benefits. The market is also regarded as more effective at responding to the continuous changes that characterize the supply and demand of this resource (which is at once mobile and costly to measure and administer), as compared to the rigidity of traditional administrative allocation methods (Lee and Juraslev, 1998).

Some studies that merit particular attention when analysing water markets in developed countries are the recent one by Hanak (2002) for California, and the joint study by the Australian Academy of Technological Sciences and Engineering (ATSE, 1999) for Australia. Likewise, the studies of Colby, Randall and Bush (1993) present wide-ranging empirical information on the operation of water markets in the arid states of the United States and find shortcomings at different levels that limit the efficiency of these markets, although this does not mean they are less efficient than schemes of an administrative nature. These studies deal with fairly mature water markets whose complexities go far beyond anything yet seen in developing countries.

An interesting study of the working of a water market in United States agriculture is that of Miller
(1987), who carries out an empirical analysis of the conditions under which a water market controlled by the owners of the resource is more efficient than a largely unregulated market, owing to the problem of externalities among interdependent irrigation users in a given water distribution system.

Studies of the workings of water markets in Chile can be grouped into two clearly defined tendencies. One group of researchers believes that the water market in Chile has had quite positive effects in terms of efficiency (Hearne and Easter, 1995; Thobani, 1997), and that this contributed to the remarkable growth of the Chilean agricultural sector in the 1980 s and 1990s.

Another group of researchers has been more cautious and suggested that the Chilean water legislation, with its clear preference for private rights, ended up by creating serious problems of hoarding and rigidity in the allocation of these rights that have not been and cannot be resolved by the market itself (Bauer, 1995; Solanes and Dourojeanni, 1995). The criticisms of this group are directed against shortcomings in the original allocation of rights and problems generated by private control of the resource, but not necessarily against the operation of the water market itself, which may be having positive effects despite its shortcomings and limitations. ${ }^{11}$

\footnotetext{
${ }^{11}$ In my own research into the workings of a water market in agriculture, in the Chilean valley of Limarí (Zegarra, 2002), I found that this market had been beneficial for agricultural development in the region, but also that its functioning could be affected by the production structure of the valley and variability in the water supply, even within a highly regulated system. Indeed, the widespread cultivation of high-value permanent crops in the valley and the occurrence of a severe drought three years in a row gave rise to certain problems for the operation of the water leasing market, including highly volatile pricing and adverse effects on short- and long-term investment.
} 


\section{VI}

\section{Conclusions}

The debate about a new water act that has been under way in Peru over the last decade indicates that the idea of introducing a market mechanism to allocate water rights is still highly controversial and very much associated with the idea of "privatization" of these rights, even though the two concepts are distinct. Protests have mainly come from agricultural users, who believe that a mechanism like that of the market would ultimately harm their interests, although they have not made it clear why this should be so.

This being the case, Peru needs to press on with a thorough debate about the advantages and disadvantages of introducing a market mechanism in the water management reform that is needed. Even if the idea is rejected, this rejection should not be formulated until the issue has been discussed in an informed way.

First of all, the current debate is still being influenced by that of the 1990s, when the proposal to create a water market was directly related to the model established by the legislation of Chile, where the introduction of a market mechanism was accompanied by water privatization. Furthermore, the original attempts to change the Peruvian water legislation were made in an increasingly authoritarian context, with little debate, so that users in the agriculture sector were left in great uncertainty about a potentially radical change in water access rules.

Thus, despite the renewal of democracy in Peru, where issues of this kind are the subject of national debate, the background referred to is still distorting the discussion of water legislation reform. Consequently, the first, indispensable task is one of conceptual clarification to draw a sharp distinction between the current proposals and those that prevailed in the 1990s (especially up to 1996) and to highlight the differences with the Chilean Water Code.

Secondly, the debate is still very polarized. For example, the subject of the water market is discussed as though there were just one single option, whereas there could be numerous formulas that included social regulation and oversight of this market in accordance with specific criteria.

The fact is that there are many possible types and degrees of markets for water, depending on the system of water rights used and the institutional arrangements for managing and regulating these. The furthestreaching option is a system of rights that can be bought and sold between and within sectors, and all of whose attributes are also tradable (leasing, mortgaging, option for future use), without the involvement of the administrative authority.

Intermediate or conditional formulas for the operation of water markets are more common in the developed countries. In particular, legislation may give the administrative authority a large share of decisionmaking power over intersectoral transactions, as very complex interests can be involved. The legislation may also give organized users themselves the power to limit transactions with other sectors or within each sector. Lastly, it may be stipulated that only a given attribute of the water right (such as temporary use, or leasing) can be traded, under set conditions defined by the user organization itself.

Looking ahead, another key challenge is to have the most thorough debate possible on the advantages and disadvantages of the water market in the case of agriculture, a sector which at present is radically opposed to this mechanism. What needs to be argued first and foremost is that this market should be subject to different degrees of administrative regulation and that it is possible to improve its functioning so that it is suited to the needs of agricultural producers in each particular case. Indeed, the very decision to introduce the market mechanism may be left for irrigation partnerships to take of their own accord, as happens in Spain.

What has to be explained, though, is that the opportunity for farmers to trade water among themselves does have some major advantages for them. The ability to quantify savings (efficiency gains) in water use creates a clear incentive to invest in techniques and practices that economize on this resource: without this incentive, farmers see no benefit from saving water and lack efficiency signals. In the face of serious soil degradation problems, this possibility is very attractive as a policy instrument. Likewise, a water market increases the overall efficiency of agricultural production in the face of large fluctuations in the water supply and gives farmers whose crops are more profitable but who are more exposed to risk when 
water fails an additional instrument to protect themselves from this eventuality.

Furthermore, with a market that operates on the basis of clearly defined water rights, farmers in conflict have incentives to resolve their disputes through commercial negotiation, which reduces the pressure on the administrative system and means that it can be oriented more towards management issues.

Again, the effect that the workings of the water market have on the equity of an irrigation system depends primarily on how well or badly other markets function, like that for finance, and on how ownership rights are allocated in the first place.

Because water is used in almost all economic and productive activities, there needs to be a multisectoral system of regulation. Agriculture is just one of the customers for water, and although important, is has to coexist in harmony with other sectors that use it. There is no one "production chain" here, but a web of interaction between sectors and user types.
This makes a far more sophisticated institutional system vital, both to establish and manage water ownership rights and to allocate water within the system of rights and laws established. In this case, the best thing is to create multisectoral authorities at the river basin level, so that this additional complexity can be dealt with at the right socio-ecological and administrative level.

The argument of this paper, then, is that in Peru it would be advisable to work towards the introduction of market mechanisms for the allocation and management of water in the different sectors, including agriculture, where the country suffers particularly from serious problems of efficiency, equity and sustainability. A reform of this kind needs to be carried out carefully and without haste, and particular consideration should be given to the shortcomings of the State itself and of irrigation organizations, which need to play an active, voluntary role in the introduction of water trading methods.
ATSE (Australian Academy of Technological Sciences and Engineering) (1999): Water and the Australian Economy, Parkville Vic, Australia, April.

Bauer, C. (1995): Property Rights, Environment and Market Institutions: Water Use, Law and Policy in Chile, 1979-1993, Berkeley, University of California.

Brisbane Institute (2002): To Market, To Market. Why Dogma Hasn't Worked with Water, Brisbane Institute, Brisbane, Australia, September.

Colby, B. (1990): Transaction costs and efficiency in western water allocation, American Journal of Agricultural Economics, vol. 72, No. 5, Massachusetts, Blackwell Publishing, December.

Colby, B., K. Randall and D. Bush (1993): Water right transactions: market value and price dispersion, Water Resources Research, vol. 29, No. 6, Florida, Water Resources Research Center.

Donoso, G. (1994): Proyecto de reforma al código de aguas: ¿mejora la asignación del recurso?, Panorama económico de la agricultura, No. 92, Santiago, Chile, Universidad Católica de Chile, January/February.

Hanak, E. (2002): California's Water Market, By the Numbers, Public Policy Institute of California, San Francisco, October.

Hearne, R. and W. Easter (1995): Water Allocation and Water Markets. An Analysis of Gains from Trade in Chile, Technical Paper, No. 315, Washington, D.C., World Bank.

Lee, T. and A. Juraslev (1998): Los precios, la propiedad y los mercados en la asignación del agua, Medio ambiente y desarrollo series, No. 6, LC/L.1097-P, Santiago, Chile, Economic Commission for Latin America and the Caribbean (ECLAC), October.

Miller, K. (1987): The rights to use versus the rights to sell: spillover effects and constraints on the water rights of irrigation organization members, Water Resources Research, vol. 23, No. 23, Florida, Water Resources Research Center.

Solanes, M. and A. Dourojeanni (1995): Mercados de derechos de agua, Debate agrario, No. 21, Lima, Centro Peruano de Estudios Sociales (CEPES), May.

Thobani, M. (1997): Formal water markets: why, when and how to introduce tradable rights in developing countries, The World Bank Research Observer, vol. 12, No. 2, Washington, D.C., World Bank, August.

Young, R. (1986): Why are there so few transactions among water users?, American Journal of Agricultural Economics, vol. 68, No. 5, Menasha, Wisconsin.

Zegarra, E. (1998): Agua, Estado y mercado: elementos institucionales y económicos, Lima, Ediciones ProA Sur.

(2002): Water Market and Coordination Failures: The Case of the Limari Valley in Chile, $\mathrm{PhD}$ dissertation, Wisconsin, University of Wisconsin-Madison.

(2003): Mercado de aguas y desarrollo agrario: explorando límites y posibilidades, Debate agrario, No. 36, Lima, Centro Peruano de Estudios Sociales (CEPES). 